\title{
Semantic Mapping or Rote Memorisation: Which Strategy Is More Effective for Students' Acquisition and Memorization of L2 Vocabulary?
}

\author{
Haytham M. Badr ${ }^{1} \&$ Emad A. S. Abu-Ayyash ${ }^{1}$ \\ ${ }^{1}$ Faculty of Education, The British University in Dubai, Dubai, United Arab Emirates \\ Correspondence: Emad A. S. Abu-Ayyash, Faculty of Education, The British University in Dubai, Dubai, DIAC, \\ Block 11, United Arab Emirates. E-mail: emad.ayyash@buid.ac.aa
}

Received: February 11, 2019

Accepted: March 12, 2019 Online Published: May 20, 2019

doi:10.5539/jel.v8n3p158

URL: https://doi.org/10.5539/jel.v8n3p158

\begin{abstract}
The present paper aimed to compare the influence of two vocabulary teaching strategies on students' vocabulary retention - roughly used in this paper to refer to the process of acquisition and memorisation. In particular, the strategies of semantic mapping and rote memorisation were compared and contrasted within a trail of evidence-based data gathered systematically from two ESL classes in an international school in the Emirate of Sharjah in the United Arab Emirates (UAE). The participants of the study were 30 male students who were in grade 12, the last stage of high school in the UAE educational system. The participants were randomly divided into two groups: a control group and an experimental group. In order to measure the impact of the two strategies under investigation on the students' vocabulary retention, the two groups sat for a pre-test and a posttest. The intervention that took place between the two tests lasted for three weeks. The results showed that the students' retrieval of the target vocabulary words improved as a result of implementing both strategies, but that the improvement which resulted from the use of semantic mapping overrode that which ensued from rote memorisation.
\end{abstract}

Keywords: semantic mapping, rote memorisation, vocabulary acquisition, vocabulary memorisation, vocabulary retention

\section{Introduction}

\subsection{An Overview on Vocabulary Memory Strategies}

Today, there are rising voices that call for more attention to vocabulary teaching and learning (e.g., AlQahtani, 2015; Ismail et al., 2017; Sa'd \& Rajabi, 2018) after a long period of negligence in academic research. Literature identified a number of reasons why second language (L2) vocabulary teaching and learning process was neglected in language classes in the past. The first reason was identified as the prevailing and long-lasting belief among language teachers and researchers that students do not need teachers' assistance to acquire new words as it was believed that they can be acquired simultaneously in natural classroom environments (Allen, 2009). The second reason was provided by Carter and McCarthy (2014), who averred that the L2 vocabulary teaching and learning process was perceived of by language teachers and researchers as an intricate web of variables involving transferring the meaning of words from one language to another, and transferring the culture of that language with the meaning. The third reason was also identified by Carter and McCarthy (2014) who referred to the scarcity of research on effective teaching strategies to be adopted in classrooms to promote L2 vocabulary teaching and learning. The result was that vocabulary teaching was replaced by grammar teaching as a less dangerous and more comfortable way to bring about the desired language learning (Brown \& Lee, 2015).

Lately, and with the development of thoughts, views and theories towards language and language learning, vocabulary teaching started to gain the necessary appreciation and attention by researchers (Alizadeh, 2016; Asyiah, 2017; Song \& Chen, 2017). For instance, Nation (2013) recognized that the lack of sufficient vocabulary knowledge base renders students unable to speak and express their ideas, thoughts and feelings effectively and properly using the target language. Moreover, Carter and McCarthy (2014) rightly aver that without grammar people can communicate, but that without vocabulary nothing can be communicated. Based on that, researchers started to look into some effective classroom strategies to boost teaching and learning of L2 vocabulary, and this 
led to the occurrence of vocabulary learning strategies. Gu and Johnson (1996) divided these strategies into four categories; vocabulary activation strategies, vocabulary cognitive strategies, vocabulary memory strategies and vocabulary meta-cognitive strategies.

By examining the vocabulary memory strategies, which are the current research focus, we found that they were also classified by Gu and Johnson (1996) into two groups; (1) the encoding group strategies which includes word structure, word association, contextual encoding, auditory encoding, visual encoding, imagery and semantic mapping, (2) the rehearsal group strategies which includes rote memorization and wordlists. These two groups were defined by Schmitt (2011) who said that the first group strategies use visuals to create connections between the target words and the existing ones in students' mind to facilitate transferring the target words from the working memory to the long-term memory for better retrieval of the target words, while the second group strategies depend in memorizing the target words on the principle of repetition and practice.

\subsection{Statement of the Problem}

Students in ELT classes have no problem accessing new words as the sources are everywhere, but the problem is to keep them in the mind for future retrieval when needed. In an attempt to solve this problem, language teachers spend most of the time allocated for language classes in teaching the new words, but when asking students later about their meanings or asking them to use the taught words in proper contexts, the result is often frustrating. To avoid this frustration, research on effective teaching strategies to be used in classrooms to reduce the time spent on vocabulary teaching with more promising results regarding the memorization of words is seen a must by the researchers of the present study. Literature shows the scarcity of research on the teaching methods that can be used to promote students' knowledge and retrieval of second language lexical items (e.g., Pudewa, 2005; Nilforoushan, 2012; Oanh \& Hien, 2006; Radwan \& Rikala-Boyer, 2011). Moreover, literature shows the scarcity of research on the most effective memory strategies that can be adopted in classrooms to prolong students' retention of L2 lexical items. In this regard, only two studies are found to explore the influence of the encoding group strategies against the rehearsal group strategies on students' memorization of L2 vocabulary, the first study of which is carried out by Sagarra and Alba (2006) and the second by Khoii and Sharififar (2013); but the results from both studies were contradictory. Within the UAE context, no studies have been so far conducted to investigate the influence of semantic mapping and rote memorisation students' knowledge base and retention of second language vocabulary.

\subsection{Rationale, Significance and Objectives of the Study}

Literature shows the scarcity of research on the influence of semantic mapping on students' knowledge and retrieval of L2 lexical items. In this regard, only two papers were done by Radwan and Rikala-Boyer (2011) and Nilforoushan (2012) to address this area of research. The results of these two papers indicate the positive influence of semantic mapping in enhancing students' knowledge and retrieval of the learnt words. In like manner, there is a lack of consensus among researchers about the influence of rote memorization on students' acquisition and memorization of words. For instance, Pudewa (2005) and Oanh and Hien (2006) argue in favor of its positive influence on students' knowledge and memorization of L2 vocabulary, while Gass and Selinker (2013) describe it in vilifying terms and aver that it has negative influence on students' creativity on the one hand, and on their understanding and memorization of the target words on the other hand.

Therefore, the researchers of the present study finds it important to do more research in this critical area in order to: (1) enrich the smidgen of research done so far, (2) reject or accept the results of the above studies in respect of the influence of memory strategies on students' acquisition and retention of words, (3) reach more definite and reliable results about the best memory strategy; semantic mapping or rote memorization, to be used to extend students' memorization of L2 lexical items.

\subsection{Questions and Hypotheses of the Study}

The researchers, on the right way to find clear answers to the following research questions, hypothesize that both semantic mapping and rote memorization are effective to enlarge students' mental lexicon, but with a greater impact by semantic mapping on students' memorization of words due to the nature of the connections built in students' minds using different visual aids. The research specifically aims to answer the following questions:

1) Do semantic mapping and rote memorization have a positive influence on students' acquisition of L2 lexical items?

2) If yes, which strategy plays a more significant role in enhancing students' memorization of words: semantic mapping or rote memorization? 


\section{Literature Review}

\subsection{Conceptual Framework}

This subsection purports to delineate the main concepts necessary to come to grips with the objectievs of the present paper. To start with, vocabulary memory strategies can be defined as effective strategies used in classrooms to prolong memorization of words by students (Gu \& Johnson, 1996). According to Coady and Huckin (2003), vocabulary acquisition, one of the perennial concepts in this paper, can be defines as a process by which the target words are learnt in proper communicative contexts. Another key notion used in this study is vocabulary memorisation, which can be defined as the ability of students to do high quality retrieval processes of the words stored in their minds (Nemati, 2013). As for semantic mapping, one of the most comprehensive definitions given to it was introduced by (Nilforoushan, 2012), who defined as the use of some drawn graphs or maps to create a connection between the target words that students need to acquire and some related words that exist in their minds to facilitate progressing the target words from the sensory memory to the working memory and into the long-term memory, leading to good retrieval of the target words. The last concept tightly relevant to the present paper is rote memorisation, which can be defined as the oral repetition of the target words many times until they are stored in students' minds for better recall when needed (Khoii \& Sharififar, 2013).

\subsection{Theoretical Framework}

\subsubsection{Theory of Language}

Language is viewed by Randall (2007) as a set of skills hierarchically acquired from the lower to higher level skills. This implies that some mental processes are required in order for students to be able to reach to, or acquire the higher-level skills. The required mental processes are compared by Richards and Rodgers (2015) to that of a computer, in that the information is first received, then processed, then delivered. This suggests that, as argued by Anderson (2015) and Randall (2007), part of this theory is behavioral as it starts with stimuli in the form of language input and ends with responses in the form of language output while in between is the information processing, and this leads to the conclusion that oral processing should be in the heart of language (Carlson et al., 2010).

\subsubsection{Theory of Language Learning}

The information processing theory of language learning was emphasized by many educationalists, scholars and researchers as the best to describe how mind works and learning occurs (e.g., Andrade, 2006; Cowen, 2008; Randall, 2007). This theory has been developed over years in an effort to understand how the new information is processed in the human mind. According to Randall (2007), this theory started with the sequential model of information processing, in which the new information should be processed through three linear processes; input, storage and output, in order for learning to occur. However, though influential, this sequential model of information processing was criticized by later theorists and researchers, such as Binder et al. (2005) and Byrnes (2001), for reducing the complexity of the human brain to only three sequential processes.

The criticism against the above model resulted in the emergence of the level of processing model, in which the information is processed in various ways; perception, attention, labeling and meaning, and the degree to which the new information is processed affects how well the new information is learnt (Randall, 2007). To put this in simple words, the deeper the new information is processed, the longer the new information is retained. However, despite its strength in changing the memory research direction, and in expanding the concentration from viewing the long-term memory as a simple vessel to store the new information to viewing it as a complex system responsible for processing any new information, this model was criticized by Eysenck and Keane (2015), among others, for not explaining how deeper processing results in better memories.

Again, the criticism of the above model led to the occurrence of the transfer-appropriate processing model, in which learning happens if the deeper processing suits the task performed. However, despite its influence, this model was called into question by Gorfein and Bubka (1997) for failing to pre-determine when the appropriate processing is best engaged with the task performed.

The big leap in the development of information processing theory came with the introduction of the connectionist model which is supported by current neuroscience research and advocated by contemporary scholars and researchers to be the best to explain how mind functions and learning occurs (e.g., Anderson, 2015; Burton, 2005; Randall, 2007). According to this theory, the new information is simultaneously kept in the human brain through some connections between the new information and the existing one. In other words, the more the connection is made between the new information and the existing one, the better the new information is memorized. 


\subsection{Memory and Storage Systems}

The general model of information processing is claimed by Anderson (2015) and Randall (2007) among others to include three memories; sensory, working/ short-term and long-term memories, and each memory is also claimed by them to have a specific definition and certain functions. The following lines summarize the general view of scholars and researchers towards the nature and functions of each memory.

The sensory memory has a very short memory and a very limited capacity, and it deals with the information that is received by the eye or the ear. This memory, despite receiving huge amounts of information, allows only for the information that is important or of particular interest to recipients to be progressed into the working/short-term memory while the unnecessary information is discarded.

The working/short-term memory is longer and larger in terms of time and capacity when compared to the sensory memory, and it deals with the auditory and/or visual information transferred from the sensory memory. There are some factors affecting information processing in the working memory. Firstly, the intellectual capacities and cognitive abilities of individuals govern the amount of information to be processed. Secondly, much repetition of information makes it automatic leading to less information processing in the mind. Thirdly, the nature of information itself in terms of necessity and relevance instinctively directs individuals' attention to make selective processing.

Unlike the above two memories, the long-term memory is of unlimited capacity and stores information for a very long time, and it deals with three types of information; imagery information (mental images), procedural information (information about how to do things) and declarative information (episodic and semantic information). The major factor affecting information processing in the long-term memory is how well information is organized. The well-organization of information happens when the information is progressed through the three memories, leading to better retrieval when needed.

\subsection{Related Studies}

The effectiveness of memory strategies on students' retention of words has been the topic of many previous studies (e.g., Abbasi, Hassaskhah, \& Tahriri, 2018; Ghorbani \& Riabi, 2011; Nemati, 2013; Sagarra \& Alba, 2006). The results from these studies showed the significant impact of memory strategies on students' retention of words on the basis that these strategies succeeded in activating the human mind to conduct high level of word processing.

Some studies were more focused to explore the effectiveness of each memory group on students' knowledge and retrieval of words. For example, the study done by Radwan and Rikala-Boyer (2011) examined the significant effect of semantic mapping on recognizing and producing the target words by students. The results showed the effectiveness of semantic mapping in enhancing word recognition and production, but the statistical difference in students' performance was only in favor of word recognition. Another study conducted by Nilforoushan (2012), in which the researcher examined the effectiveness of semantic mapping on students' realization of the two-word dimensions; the evaluative dimension (positive or negative impact of word meaning) and the potency dimension (potent or non-potent impact of word meaning). The result revealed the positive impact of semantic mapping on the two-word knowledge dimensions.

Literature also fed us with some studies on the effectiveness of rehearsal strategies on word knowledge and retention including the one conducted by Parle, Singh and Vasudevan (2006), in which the researchers examined their influence on students' memorization of words after eighteen days, and the results were very positive. Another study carried out by Kuo and Ho (2012), in which the researchers looked into the effectiveness of one of rehearsal strategies (wordlist) against one of traditional strategies (word card) on students' memorization of words. The result from this study indicated the significant difference in students' performance in favor of wordlists.

Finally, literature showed only one study conducted by Khoii and Sharififar (2013) to check the significant effect of semantic mapping against rote memorization on students' knowledge and recall of words. The result of this study revealed the same positive impact of both strategies on students' knowledge and memorization of words if either of them is employed in classroom settings.

\section{Methodology}

\subsection{Research Design}

This study aims to find out the influence of semantic mapping versus rote memorization on students' knowledge and memorization of second language lexical items. To achieve this aim, the experimental method, a type of 
quantitative research methods by Walliman (2009), was adopted. The experimental method is defined by Creswell (2014) as a quantitative research method through which accurate and numerical data are collected. This method was particularly adopted in this study because it is considered the best to check the influence of an experiment on students' learning (Johnson \& Christensen, 2016). Therefore, the researchers of this study think that this method sits comfortably well with the objectives of the current research.

The researchers' tools, as annexed in the appendix (A) to this study, are three tests; pre-test, post-test and delayed post-test, in multiple-choice formats as the concentration in the current study is given to recognition of words rather than production of words. It is worthy of note that the content of the pre-test is the same as the content of the other two tests but with the content re-organized to remove any worries concerning the retention of answers by students.

\subsection{Research Scope, Context and Materials}

Two ESL classes, 12-grade classes, totaling thirty male students, evenly distributed and randomly chosen from a reputable international private school called "Sharjah International Pvt. School" and located in Sharjah Emirates, are used to be the main sample of this study. This school is particularly chosen because it is authorized by the UAE Ministry of Education to offer accredited teaching services of different academic subjects encompassing teaching English as a foreign language to speakers of other languages. One of the two classes are arbitrarily selected to be the experimental group and then assigned the semantic mapping, and the other is arbitrarily selected to be the control group and then assigned the rote memorization. Randomisation of the classes was done through a fish bowl selection as there were a total of 6 classes to select from. These classes were given numbers from 1 to 6 and the two classes were selected randomly from these.

The participants' age ranges between 17 and 18 years old, and they study English as a second language for almost ten years. They are also taught the English language subject by one teacher who is asked to take part in the experiment on a voluntary basis. The teacher, a male teacher, is not a native speaker of the target language, the English language but equipped with a long experience in the field, almost eleven years in the UAE context, enabling him to effectively take part in in the experiment. The research materials are fifteen words taken from four reading passages in the students' course book "Bridge to Success" by E. Borecki, Z. Smith, R. Brettell, M. Cullinan, Z. Al Baloushi and A. Behan (2018), term (3) material. The four reading passages, from which the fifteen target words are taken, are selected from the second unit and annexed in the appendix (B) to this research. It is worthy of note that the fifteen target words are typified as low-frequent words by the pre-test at the beginning of the experiment.

\subsection{Procedure}

After the homogeneity of all participants in terms of their low knowledge of the examined words was secured through a pre-test given to both groups, both the experimental and control groups were exposed to the target words for three consecutive days using the semantic mapping for the experimental group and the rote memorization for the control group. Students' performance in the examined words was measured at the end of three weeks using the post-test. Three days later, the delayed-post test was administered to make sure that the post-test results were reliable.

During the three days of instruction, the teacher started the experimental group's class with assigning a student to loudly read the selected passages while he wrote the target words on the blackboard once read. After that, the teacher asked the students to provide related words to the written ones. He, then, drew some connected squares or circles around each correct answer provided by the students. The remaining time of the class was utilized in doing some comprehension-related activities without any further tasks inside or outside the class. The control group class, on the other hand, had the same start and the same end but the teacher's role was different, as he here asked the students to repeat the written words over and over until they were retained in the students' mind.

\subsection{Issues Foreseen by the Researchers}

\subsubsection{Validity, Reliability and Objectivity}

Creswell (2014) suggests some techniques to enhance the validity, reliability and objectivity of experimental studies. This includes providing external judges to check the three tests along with students' answers for any mistakes, administering a delayed post-test to confirm the results of the post-test and allowing for class teachers to teach research materials themselves. The three techniques above along with other procedures; such as using the same time and scoring system and keeping the date and time of tests unknown for students and instructing class teachers on how to successfully employ the investigated strategies in the classroom setting, are taken into account by the researchers to respectively enhance the current research validity, reliability and objectivity. 


\subsubsection{Ethical and Entry Issues}

The researchers are fully aware of other important issues that may impede the successful completion of the research. These issues include getting the necessary approval from the school principal, arranging for a meeting with the class teacher to instruct him on how to properly employ the two investigated strategies in the classroom, respecting all students and protecting their privacy, pledging in front of the school principal and other school representatives not to, under any condition, misuse the results of this study aiming at disfiguring the school reputation, and finally clarifying the purpose of this research whenever asked to do so. These issues are deemed important by Hesse-Biber and Leavy (2011), and then taken into consideration by the researchers of the present study.

\section{Data Analysis and Findings}

\subsection{Answering the First Research Question}

\subsubsection{Students' Low Knowledge of Words before the Experiment}

The data collected from the pre-test is first tested for normality using the Statistical Program for Social Sciences (SPSS), version 23. The results reveal that the significance (P value) on both Shapiro and Kolmongorov tests is higher than (0.05) for both the experimental and control groups as shown in Table 1, indicating the normal distribution of data.

Table 1 . Tests of normallty

\begin{tabular}{lllllll}
\hline & \multicolumn{6}{l}{ Kolmogorov-Smirnov $^{\text {a }}$} \\
\cline { 2 - 7 } & Statistic & df & Sig. & Statistic & df & Sig. \\
\hline Experimental Group before & .166 & 15 & $.200^{*}$ & .956 & 15 & .631 \\
Control Group before & .209 & 15 & .076 & .910 & 15 & .134 \\
\hline
\end{tabular}

Note. ${ }^{*}$. This is a lower bound of the true significance.

a. Lilliefors Significance Correction.

The data are then analyzed for mean values using the SPSS Descriptive Statistics to check the homogeneity of participants in terms of their low knowledge level of the investigated words. The results, as illustrated in Table 2, indicate no big difference in the low mean values between both groups before the experiment $(\mathrm{MD}=2.60-1.87$ $=0.73$ ).

Table 2. Descriptive statistics

\begin{tabular}{llllll}
\hline & N & Minimum & Maximum & Mean & Std. Deviation \\
\hline Experimental Group before & 15 & 0 & 6 & 2.60 & 1.765 \\
Control Group before & 15 & 0 & 4 & 1.87 & 1.246 \\
Valid N (listwise) & 15 & & & & \\
\hline
\end{tabular}

The above mean difference (MD) is also measured for the statistical significance using the SPSS Independent Sample T-test. The result, as in Table 3 below, reveals that the significance values when equal variances are assumed and when equal variances are not assumed are $(\mathrm{P}=0.19 \& 0.20$ respectively), and both values are higher than the significance $(\mathrm{P}=0.05)$, indicating that the difference is statistically insignificant.

Table 3. Independent samples test

\begin{tabular}{|c|c|c|c|c|c|c|c|c|c|}
\hline & \multicolumn{2}{|c|}{$\begin{array}{l}\text { Levene's Test for } \\
\text { Equality of } \\
\text { Variances }\end{array}$} & \multicolumn{7}{|c|}{ t-test for Equality of Means } \\
\hline & \multirow[t]{2}{*}{$\mathrm{F}$} & \multirow[t]{2}{*}{ Sig } & \multirow[t]{2}{*}{$\mathrm{t}$} & \multirow[t]{2}{*}{$\mathrm{df}$} & \multirow[t]{2}{*}{$\begin{array}{l}\text { Sig. } \\
\text { (2-talied) }\end{array}$} & \multirow[t]{2}{*}{$\begin{array}{l}\text { Mean } \\
\text { Difference }\end{array}$} & \multirow[t]{2}{*}{$\begin{array}{l}\text { Std. Error } \\
\text { Difference }\end{array}$} & \multicolumn{2}{|c|}{$\begin{array}{l}95 \% \text { Confidence } \\
\text { Interval of the } \\
\text { Difference }\end{array}$} \\
\hline & & & & & & & & Lower & Upper \\
\hline $\begin{array}{l}\text { marks Equal variances } \\
\text { assumed }\end{array}$ & 2.256 & .144 & 1.315 & 28 & .199 & .733 & .558 & -.409 & 1.876 \\
\hline $\begin{array}{l}\text { Equal variances not } \\
\text { assumed }\end{array}$ & & & 1.315 & 25.179 & .200 & .733 & .558 & -.415 & 1.882 \\
\hline
\end{tabular}




\subsubsection{Students' Knowledge of Words After the Experiment}

The same data normal distribution test done for both groups before the experiment is done for both groups after the experiment to make sure that the data collected from the post-test is measurable and applicable to other tests. The results, as presented in Table 4, show that the significance values on both Kolmongorov and Shapiro tests are greater than $(0.05)$ for both groups ( $\mathrm{P}$ value $=0.2 \& 0.2$ respectively), indicating the normal distribution of data.

Table 4. Tests of normality

\begin{tabular}{|c|c|c|c|c|c|c|}
\hline & \multicolumn{3}{|c|}{ Kolmogorov-Smirnov ${ }^{a}$} & \multicolumn{3}{|c|}{ Shapiro-Wilk } \\
\hline & Statistic & $\mathrm{df}$ & Sig. & Statistic & $\mathrm{df}$ & Sig. \\
\hline EG. After & .167 & 15 & $.200^{*}$ & .939 & 15 & .368 \\
\hline CG. After & .141 & 15 & $.200^{*}$ & .963 & 15 & .743 \\
\hline
\end{tabular}

Note. ${ }^{*}$ This is a lower bound of the true significance.

a. Lilliefors Significance Correction.

The data are then analyzed for the mean scores using the SPSS Descriptive Statistics to check both groups' performance at the end of the experiment. The results, as displayed in Table 5 below, show that the experimental group's mean after the experiment $(\mathrm{M}=11)$ is much greater than the same group's mean before the experiment $(\mathrm{M}=2.60)$, unraveling the great influence of semantic mapping on students' acquisition of the target words. In like manner, the results show that the control group's mean after the experiment $(\mathrm{M}=8.33)$ is much higher than the same group's mean before the experiment $(\mathrm{M}=1.87)$, unveiling the important role played by rote memorization in enhancing students' acquisition of the target words.

Table 5. Descriptive statistics

\begin{tabular}{llllll}
\hline & N & Minimum & Maximum & Mean & Std. Deviation \\
\hline EG. After & 15 & 5 & 15 & 11.00 & 2.903 \\
CG. After & 15 & 5 & 12 & 8.33 & 2.059 \\
Valid N (listwise) & 15 & & & & \\
\hline
\end{tabular}

\subsection{Answering the Second Research Question}

The mean difference (MD) of both groups after the experiment is measured using the SPSS Descriptive Statistics to check whether semantic mapping or rote memorization has a greater effect on students' memorization of words over time. The results, as presented in Table 6 below, indicate that the difference in the mean scores of both groups after the experiment is $(\mathrm{MD}=11-8.33=2.67)$ in favor of the experimental group. By recalling the mean difference of both groups before the experiment, we find that the mean difference is increased by (1.94) in favor of the semantic mapping after both strategies are employed, unveiling the superiority of semantic mapping over rote memorization concerning with students' memorization of words.

Table 6. Descriptive statistics

\begin{tabular}{llllll}
\hline & $\mathrm{N}$ & Minimum & Maximum & Mean & Std. Deviation \\
\hline Experimental Group before & 15 & 0 & 6 & 2.60 & 1.765 \\
Control Group before & 15 & 0 & 4 & 1.87 & 1.246 \\
EG. After & 15 & 5 & 15 & 11.00 & 2.903 \\
CG. After & 15 & 5 & 12 & 8.33 & 2.059 \\
Valid N (listwise) & 15 & & & & \\
\hline
\end{tabular}

Finally, the SPSS Independent Sample T-test is done for both groups after the experiment to check the statistical significance of the mean difference. The results, as in Table 7 below, reveal that the significance values of the $t$-test when equal variances are assumed and when equal variances are not assumed are ( $\mathrm{P}$ value $=0.00 \& 0.00$ respectively), and these two values are lower than the significant value $(\mathrm{P}=0.05)$, unveiling the statistical significance of the mean difference. 
Table 7. Independent samples test

\begin{tabular}{|c|c|c|c|c|c|c|c|c|c|c|}
\hline & & \multicolumn{2}{|c|}{$\begin{array}{l}\text { Levene's Test for } \\
\text { Equality of } \\
\text { Variances }\end{array}$} & \multicolumn{7}{|c|}{ t-test for Equality of Means } \\
\hline & & \multirow[t]{2}{*}{$\mathrm{F}$} & \multirow[t]{2}{*}{ Sig } & \multirow[t]{2}{*}{$\mathrm{t}$} & \multirow[t]{2}{*}{$\mathrm{df}$} & \multirow[t]{2}{*}{$\begin{array}{l}\text { Sig. } \\
\text { (2-talied) }\end{array}$} & \multirow[t]{2}{*}{$\begin{array}{l}\text { Mean } \\
\text { Difference }\end{array}$} & \multirow[t]{2}{*}{$\begin{array}{l}\text { Std. Error } \\
\text { Difference }\end{array}$} & \multicolumn{2}{|c|}{$\begin{array}{l}95 \% \text { Confidence } \\
\text { Interval of the } \\
\text { Difference }\end{array}$} \\
\hline & & & & & & & & & Lower & Upper \\
\hline \multirow[t]{2}{*}{$\begin{array}{l}\text { marks after the } \\
\text { experiment }\end{array}$} & $\begin{array}{l}\text { Equal variances } \\
\text { assumed }\end{array}$ & 1.220 & .279 & 2.902 & 28 & .007 & 2.667 & .919 & .784 & 4.549 \\
\hline & $\begin{array}{l}\text { Equal variances } \\
\text { not assumed }\end{array}$ & & & 2.902 & 25.238 & .008 & 2.667 & .919 & .775 & 4.558 \\
\hline
\end{tabular}

\section{Discussion}

The results show the homogeneity of participants in terms of their low knowledge level of the investigated lexical items at the outset of the experiment as the difference in the mean values is identified as (MD $=0.73$ ) and this difference is statistically insignificant when both equal variances and unequal variances are assumed (P-values $>0.05)$. The results also show an outstanding performance in students' knowledge base of the examined items after both strategies are assigned in the classrooms under investigation, and this is noticed in the mean values of both groups at the end of the experiment $(\mathrm{M}=11 \& 8.33)$ for both the experimental group and the control group respectively. This leads to the conclusion that both semantic mapping and rote memorization can be used in the classroom setting to boost students' acquisition of second language vocabulary in agreement with other studies (e.g., Ghorbani \& Riabi, 2011; Khoii \& Sharififar, 2013; Nilforoushan, 2012; Radwan \& Rikala-Boyer, 2011), in which both strategies are effective to enlarge students' knowledge of L2 vocabulary if used in the classroom context.

The results of the present study also show that there is a difference in students' performance in favor of semantic mapping after both strategies are employed, and this difference is statistically significant when both equal variances and unequal variances are assumed (P-values $<0.05$ ). It is then concluded that semantic mapping will always have a greater impact on students' memorization of words than rote memorization in contradiction with the study carried out by Khoii and Sharififar (2013), in which no superiority is given to semantic mapping over rote memorization despite the mental energy and time consumed by semantic mapping to prepare the semantic maps.

Notwithstanding, and by looking deep into the principles of two models of the information processing theory; the deep mental processing model and the connectionist model, we find that the superiority of semantic mapping over rote memorization is logical. To explain this, semantic mapping is based on creating connections in students' mental lexicon, and this requires deep mental word processing as argued by Thornbury (2015), while rote memorization is based on much repetition of words making them automatic in students' mind and this needs less mental word processing as argued by Randall (2007). Moreover, and unlike rote memorization, semantic mapping uses visual aids to enhance the connection of words in students' mind, leading to easy transfer of words from the sensory to the short-term and into the long-term memory which results in word organization and good retrieval processes as a consequence (Randall, 2007).

Ultimately, and because of the time and energy consumed in preparing semantic maps in classrooms as corroborated by Khoii and Sharififar (2013), teachers may go to the class with pre-conceived maps, but this is against the principles of information processing theory which see students as the main source of information who have the cognitive abilities that enable them to progress the information across the three linear processes of information; reception, storage and retrieval of information. If teachers go to the class with pre-planned maps, this may result in restricting students' creativity in making more connections between words on one hand and confining the connections to some words already determined by teachers not by students on the other hand, and the result is that low mental word processing and poor retrieval word processing as a consequence.

\section{Conclusion, Limitations and Recommendations}

It is concluded from this study that although an improvement is seen after both semantic mapping and rote memorization are employed in the classrooms under investigation, this improvement is statistically significant in favor of semantic mapping, recommending the use of semantic mapping to better extend students' memorization of words. The superiority of semantic mapping over rote memorization may be attributed to the nature of the 
connections built in the mental lexicon of students and to the visual aids used to enhance such connections. Other advantages of semantic mapping are noticed in its ability to improve other skills; such as students' cognitive and metal cognitive skills through the deep mental word processing, and this happens when students build networks of interrelated words in their mental lexicon (Thornbury, 2015).

Moreover, semantic mapping can be used to improve students' social skills through students' full participation and involvement with their teachers and other classmates in creating connections between words especially when unfixed semantic maps are used (Seedhouse, 2004). Therefore, it is highly recommended to use semantic mapping to better extend students' memorization of words leaving the semantic maps to be determined by students in the class to maximize students' benefit from semantic mapping as a vocabulary memory strategy and at the same time to improve other cognitive and social skills.

However, although the two research questions are clearly answered and the two research hypotheses are evidently confirmed, the following two points should be considered when interpreting the current research results.

1) Due to the complex and lengthy administrative procedures represented in obtaining the necessary approvals from the current research site to enlarge the current sample, the researchers had to conduct the present study on this small number of participants. It would be more beneficial to conduct the study on a larger number of participants to enhance the well-representation of the current sample to the society and to get access to more invaluable information which may lead to more significant findings.

2) Due to the limited time allocated to conduct the current research, the participants are exposed to the investigated words for only three time in three consecutive days, and according to Nation and Wang (1999), the new words are best memorized if the exposure happens for at least ten times.

Therefore, it is recommended to duplicate this study putting in mind the above limitations and investigating students from other educational levels to obtain more reliable results with regard to the most effective vocabulary memory strategy that can be used in classrooms to boost students' memorization of words. Furthermore, other studies may be conducted to compare semantic mapping to other memory strategies; such as word association, auditory encoding or memorization by over-learning, on students' memorization of words. Finally, it might be beneficial to investigate the UAE teachers' view towards the effectiveness of semantic mapping as a vocabulary memory strategy to check how successful this strategy can be implemented in the UAE context.

\section{Reference}

Abbasi, A., Hassaskhah, J., \& Tahriri, A. (2018). The effect of teaching memory strategies on Iranian EFL learners' vocabulary retention in terms of learners' multiple intelligences. International Journal of Education \& Literacy Studies, 6(2), 1-9.

Alizadeh, I. (2016). Vocabulary teaching techniques: A review of common practices. International Journal of Research in English Education, 1(1), 22-30.

Allen, V. F. (2009). Techniques in teaching vocabulary. New York; Oxford: Oxford University Press.

AlQahtani, M. (2015). The importance of vocabulary in language learning and how to be taught. International Journal of Teaching and Education, 3(3), 21-34. https://doi.org/10.20472/TE.2015.3.3.002

Anderson, J. (2015). Cognitive psychology and its implications (8th ed.). New York: Worth Publishers. https://doi.org/10.1016/j.cogpsych.2015.07.002

Andrade, J. (2006). Working memory in perspective. Hove: Psychology Press.

Asyiah, D. N. (2017). The vocabulary teaching and vocabulary learning: Perception, strategies, and influences on students' vocabulary mastery. Jurnal Bahasa Lingua Scientia, 9(2), $293-318$. https://doi.org/10.21274/1s.2017.9.2.293-318

Binder, J., Medler, D., Desai, R., Conant, L., \& Liebenthal, E. (2005). Some neurophysiological constraints on models of word naming. NeuroImage, 27(3), 677-693. https://doi.org/10.1016/j.neuroimage.2005.04.029

Brown, H., \& Lee, H. (2015). Teaching by principles: an interactive approach to language pedagogy (4th ed.). White Plains, N.Y.: Pearson Education.

Burton, M. W., Locasto, P. C., Krebs-Noble, D., \& Gullapalli, R. P. (2005). A systematic investigation of the functional neuroanatomy of auditory and visual phonological processing. NeuroImage, 26(3), 647-661. https://doi.org/10.1016/j.neuroimage.2005.02.024 
Byrnes, J. (2001). Minds, brains, and learning: understanding the psychological and educational relevance of neuroscientific research. New York: Guilford Press.

Carlson, N., Miller, H., Heth, C., Donahoe, J., \& Martin, G. (2010). Psychology: the science of behavior (7th ed.). Boston: Allyn \& Bacon.

Carter, R., \& McCarthy, M. (2014). Vocabulary and language teaching. Hoboken: Taylor and Francis. https://doi.org/10.4324/9781315835860

Coady, J., \& Huckin, T. (2003). Second language vocabulary acquisition: a rationale for pedagogy. Cambridge: Cambridge University Press.

Cowen, N. (2008). Attention and memory: an integrated framework. Oxford: Oxford University Press.

Creswell, J. (2014). Research design: qualitative, quantitative, and mixed methods approaches (4th ed.). Thousand Oaks, California: Sage Publications.

Eysenck, M., \& Keane, M. (2015). Cognitive psychology: A student's handbook (7th ed.). Abingdon, Oxon: Psychology Press. https://doi.org/10.4324/9781315778006

Gass, S., \& Selinker, L. (2013). Second language acquisition: An introductory course (4th ed.). London: Routledge. https://doi.org/10.4324/9780203137093

Ghorbani, M. R., \& Riabi, N. K. (2011). The impact of memory strategy instruction on learners' EFL vocabulary retention. Theory and Practice in Language Studies, 1(9), 1222-1226. https://doi.org/10.4304/tpls.1.9.1222-1226

Gorfein, D. S., \& Bubka, A. (1997). A transfer analysis of the repetition effect in the lexical and ambiguity decision tasks. Psychonomic Bulletin \& Review, 4(2), 232-236.: https://doi.org/10.3758/BF03209398

$\mathrm{Gu}$, Y., \& Johnson, R. K. (1996). Vocabulary learning strategies and languages learning outcomes. Language Learning, 46(4), 1467-1770. https://doi.org/10.111/j.1467-1770.1996.tb01355.x

Hesse-Biber, S., \& Leavy, P. (2011). The practice of qualitative research (2nd ed.). Thousand Oaks, California: Sage Publications.

Isamil, N. S., Zaid, S. B., Mohamed, M. H., \& Rouyan, N. M. (2017). Vocabulary teaching and learning principles in classroom practices. Arab World English Journal, 8(3), 119-134. https://doi.org/10.24093/awej/vol8no3.9

Johnson, B., \& Christensen, L. (2016). Educational research: quantitative, qualitative, and mixed approaches (6th ed.). Thousand Oaks, California: Sage Publications. https://doi.org/10.3102/0013189X16656939

Khoii, R., \& Sharififar, S. (2013). Memorization versus semantic mapping in L2 vocabulary acquisition. ELT Journal: English Language Teaching Journal, 67(2), 199-209. https://doi.org/10.1093/elt/ccs101

Kuo, Y., \& Ho, H. Y. (2012). Effects of word card strategy versus word list strategy on Taiwanese EFL junior high school students' vocabulary retention. Electronic Journal of Foreign Language Teaching, 9(1), 26-45.

Nation, I. (2013). Learning vocabulary in another language (2nd ed.). Cambridge: Cambridge University Press. https://doi.org/10.1017/CBO9781139858656

Nation, P., \& Wang Ming-tzu, K. (1999). Graded readers and vocabulary. Reading in a Foreign Language, 12(2), $355-379$.

Nemati, A. (2013). Vocabulary learning strategies: a short way to long term retention. Linguistics and Literature Studies,1(1), 8-14.

Nilforoushan, S. (2012). The effect of teaching vocabulary through semantic mapping on EFL learners' awareness of the affective dimensions of deep vocabulary knowledge. English Language Teaching, 5(10), 164-172. https://doi.org/10.5539/elt.v5n10p164

Oanh, D., \& Hien, N. (2006). Memorization and EFL students' strategies at university level in Vietnam. TESL-EJ, 10(2), 1-21.

Parle, M., Singh, N., \& Vasudevan, M. (2006). Regular rehearsal helps in consolidation of long-term memory. Journal of Sports Science and Medicine, 5(1), 80-88.

Pudewa, A. (2005). Linguistic development through poetry memorization: a mastery learning approach. Atascadero, CA: Institute for Excellence in Writing. 
Radwan, A. A., \& Rikala-Boyer, J. (2011). Semantic processing and vocabulary development of adult ESL learners. Asian Journal of English Language Teaching, 21, 1-21.

Randall, M. (2007). Memory, psychology and second language learning. Amsterdam/Philadelphia: John Benjamin Publishing Co. https://doi.org/10.1075/1llt.19

Richards, J., \& Rodgers, T. (2015). Approaches and methods in language teaching (3rd ed.). Cambridge: Cambridge University Press.

Sa'd, S. H. T., \& Rajabi, F. (2018). Teaching and learning vocabulary: What English Language learners perceive to be effective and ineffective strategies. C.E.P.S. Journal, 8(1), 139-163.

Sagarra, N., \& Alba, M. (2006). The key is the keyword: L2 vocabulary learning methods with beginning learners of Spanish. Modern Language Journal, 90(2), 228-243. https://doi.org/10.1111/j.1540-4781.2006.00394.x

Schmitt, N. (2011). Vocabulary learning strategies. In N. Schmitt \& M. McCarthy (Eds), Vocabulary: description, acquisition and pedagogy (pp. 199-227). Cambridge: Cambridge University Press.

Seedhouse, P. (2004). The interactional architecture of the language classroom: a conversation analysis perspective. Malden, MA: Blackwell.

Song, M., \& Chen, L. (2017). A review on English vocabulary acquisition and teaching research in recent 30 years in China. Science Journal of Education, 5(4), 174-180. https://doi.org/10.11648/j.sjedu.20170504.18

Thornbury, S. (2015). How to teach vocabulary. Harlow: Pearson Educated Limited.

Walliman, N. (2009). Your research project: a step-by-step guide for the first-time researcher (2nd ed.). Los Angeles: Sage Publications.

\section{Appendix A}

\section{The Research Tools}

The pre-test

\section{$\underline{\text { Students' answer sheet }}$}

Students' Name: Class No.: Mark: $/ 40$

Please circle the answer that is closest in the meaning to the underlined words. Please choose only one answer.

1) His defeat in the world championship led to a long period of gloomy introspection.

a- self-love b- self-analysis c- despair d- segregation

2) He approached the problem in the best way.

a- solved b- raised c-tackled d-progressed

3) The music students here are a very introvert lot.

a- sensational b- romantic c- shy d- enthusiastic

4) Your insights and intuitions as a native speaker are positively sought.

a- suspicion b- abilities c- language d- instinct

5) Implementation of the reforms was kept to a very strict timetable.

a- plan b- schedule c- decision d- furniture

6) So much is conveyed by gesture.

a- body signal b- emotion c- speaking d- light

7) The warmth in his voice disarmed her.

a- discouraged b-blinded c-calmed d-triggered

8) He made no attempt to conceal his smirk.

a- ego b- fear c- anger d- silly smile

9) He looked at the coded message, frowning in concentration.

a- staring b- thinking c- replying d- looking angrily 
10) The changes cannot be made until the country's right to self-determination is recognized.
a- being independent
b- freedom
c- self-control
d- make profits

11) Their intimate friendship to each other is largely praised.
a- active
b- close
c- wide
d- intensive

12) There's always a lack of consistency in matters of foreign policy.
a- agreement
b- pleasure
c- controversy
d- constancy

13) The boy scowled at her and reluctantly followed her back into school.
a- smiled
b- yelled angrily
c- twinkled
d- look annoyingly

14) He is a reserved, almost taciturn man.
a- talkative
b- uncommunicative
c- extroverted
d- sensitive

15) She was primarily motivated by the desire for profit.
a- prompted
b- intimidated
c- ticked
d- hit

The post-test

\section{Students' answer sheet}

Students' Name: Class No.: Mark: 140

Please circle the answer that is closest in the meaning to the underlined words. Please choose only one answer.

1) He approached the problem in the best way.
a- solved
b- raised
c- tackled
d- progressed

2) Your insights and intuitions as a native speaker are positively sought.

a- suspicion b-abilities c- language d- instinct

3) The music students here are a very introvert lot.
a- sensational
b- romantic
c- shy
d- enthusiastic

4) Implementation of the reforms was kept to a very strict timetable.
a- plan
b- schedule
c- decision
d- furniture

5) The warmth in his voice disarmed her.
a- discouraged
b- blinded
c- calmed
d- triggered

6) He looked at the coded message, frowning in concentration.
a- staring
b- thinking
c- replying
d- looking angrily

7) He made no attempt to conceal his smirk.
a- ego
b- fear
c- anger
d- silly smile

8) So much is conveyed by gesture.

a- body signal b- emotion c- speaking d- light

9) The changes cannot be made until the country's right to self-determination is recognized.

a- being independent b- freedom c- self-control d-make profits

10) She was primarily motivated by the desire for profit.
a- prompted
b- intimidated
c- ticked
d- hit

11) Their intimate friendship to each other is largely praised.
a- active
b- close
c- wide
d- intensive

12) The boy scowled at her and reluctantly followed her back into school.
a- smiled
b- yelled angrily
c- twinkled
d- look annoyingly

13) There's always a lack of consistency in matters of foreign policy. 

a- agreement
b- pleasure
c- controversy
d- constancy

14) He is a reserved, almost taciturn man.
a- talkative
b- uncommunicative
c- extroverted
d- sensitive

15) His defeat in the world championship led to a long period of gloomy introspection.
a- self-love
b- self-analysis
c- despair
d- segregation

\section{The delayed post-test}

\section{Students' answer sheet}

Students' Name: Class No: $\quad$ Mark: $/ 40$

Please circle the answer that is closest in the meaning to the underlined words. Please choose only one answer.

1) Their intimate friendship to each other is largely praised.
a- active
b- close
c- wide
d- intensive
2) The warmth in his voice disarmed her.
a- discouraged b-blinded c-calmed d-triggered

3) Your insights and intuitions as a native speaker are positively sought.

a- suspicion b-abilities c- language d-instinct

4) So much is conveyed by gesture.

a- body signal b- emotion c- speaking d- light

5) He approached the problem in the best way.
a- solved
b- raised
c- tackled
d- progressed

6) He is a reserved, almost taciturn man.
a- talkative
b- uncommunicative
c- extroverted
d- sensitive

7) The changes cannot be made until the country's right to self-determination is recognized.
a- being independent $\quad b$ - freedom
c- self-control
d- make profits

8) The boy scowled at her and reluctantly followed her back into school.
a- smiled
b- yelled angrily
c- twinkled
d- look annoyingly

9) He looked at the coded message, frowning in concentration.
a- staring
b- thinking
c- replying
d- looking angrily
10) The music students here are a very introvert lot.
a- sensational
b- romantic
c- shy
d- enthusiastic

11) She was primarily motivated by the desire for profit.
a- prompted
b- intimidated
c- ticked
d- hit

12) Implementation of the reforms was kept to a very strict timetable.
a- plan
b- schedule
c- decision
d- furniture

13) He made no attempt to conceal his smirk.
a- ego
b- fear
c- anger
d- silly smile

14) His defeat in the world championship led to a long period of gloomy introspection.
a- self-love
b- self-analysis
c- despair
d- segregation

15) There's always a lack of consistency in matters of foreign policy.
a- agreement
b- pleasure
c- controversy
d- constancy 


\section{Appendix B}

The Research Material

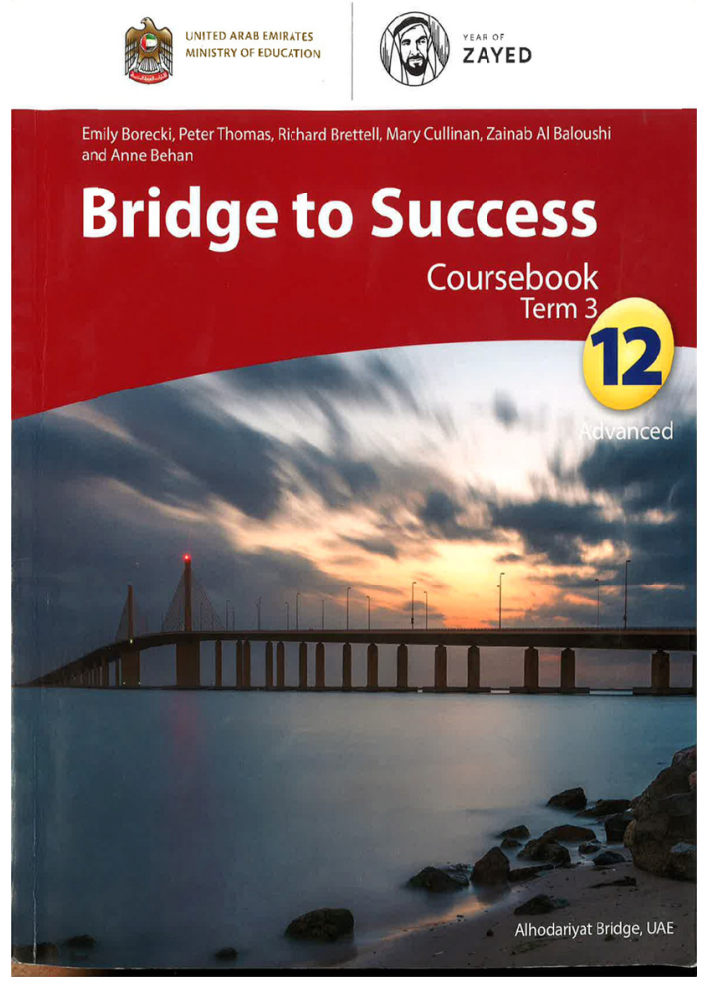

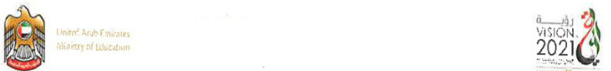

\section{Bridge to Success}

\section{Coursebook}

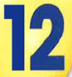

Emily Borecki, Zachary Smith,

Richard Brettel, Mary Cullinan,

Zainab Al Baloushi and Anne Behan 
Contents
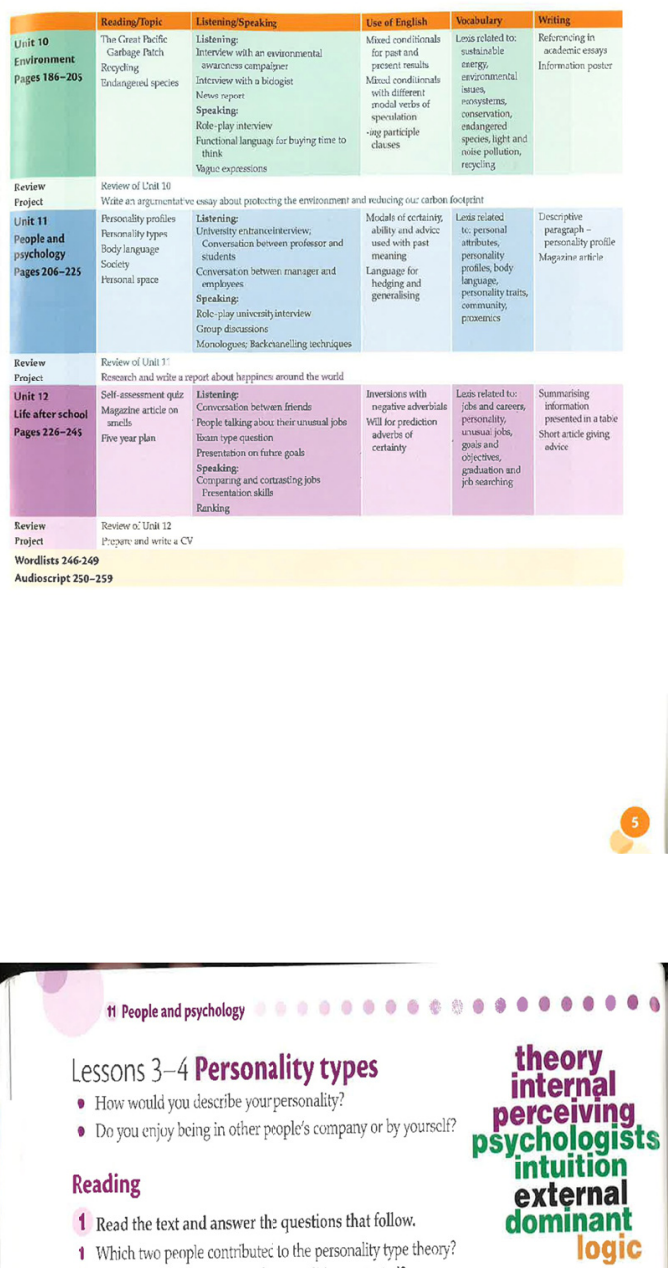

1 Read the text and answer the questions that follow.

1 Which two people contributec to the personality type theory?

2. How many different arcas of personalities arc tested?

3 How many different types of personality can be identilied by this personality test?

4 Why du you think there is a capital $N$ in iNtuition in this text?

5 If someone was IST] what for personality types would they be?

6 If someone was ENF] would they be more ikely to stick to their pians or not have any plant

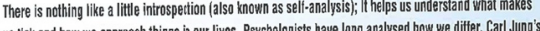

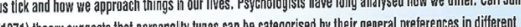

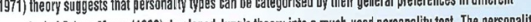
areas. I sabel brgys hiyos ( tast identities peoples' preterenceses arross tour titierent

The icur fifferent raess at:

- Introvert Vextrovert (IE): Reters s the soucc of

aperson's energy. An extrover mainly couses on thite

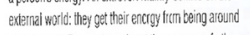

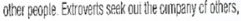

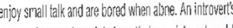

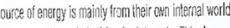

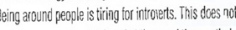

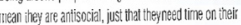

own; they recharge when a one.

- Sensing V illturtion (SN): Réess n the way sonmegen

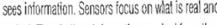

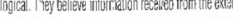

werld. Thuition on the cher hand megs tra. a petson

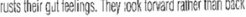

- Thinking V Feeling (TF): Reters to the kay sonneore makkes a decision and deals wilh enolicns. Thinking mears liatl a person dexides neiny based ton ogic and consistency. Thirlers use theil hads adilet than their

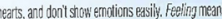
Itate parcon corides things bassd on enclion, or the specif set of cirennistences

Judging V Perceiving (JP): Héers to tow pooplie

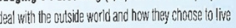

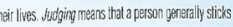

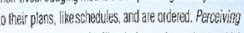
and cteter enioy strange rewi iteas.

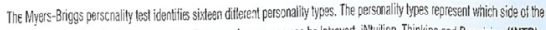

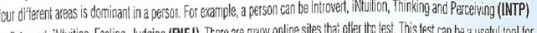

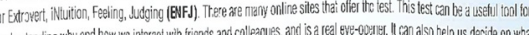

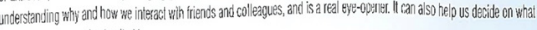
kinind of cares we we ate bast suted to.

210. Unit 11 Lessons 3-4 

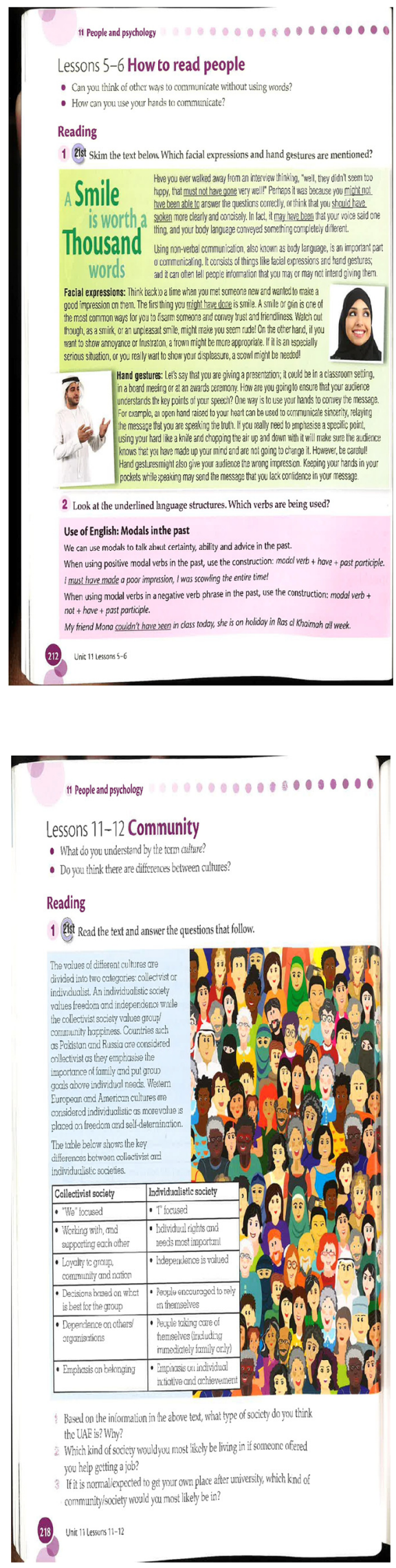


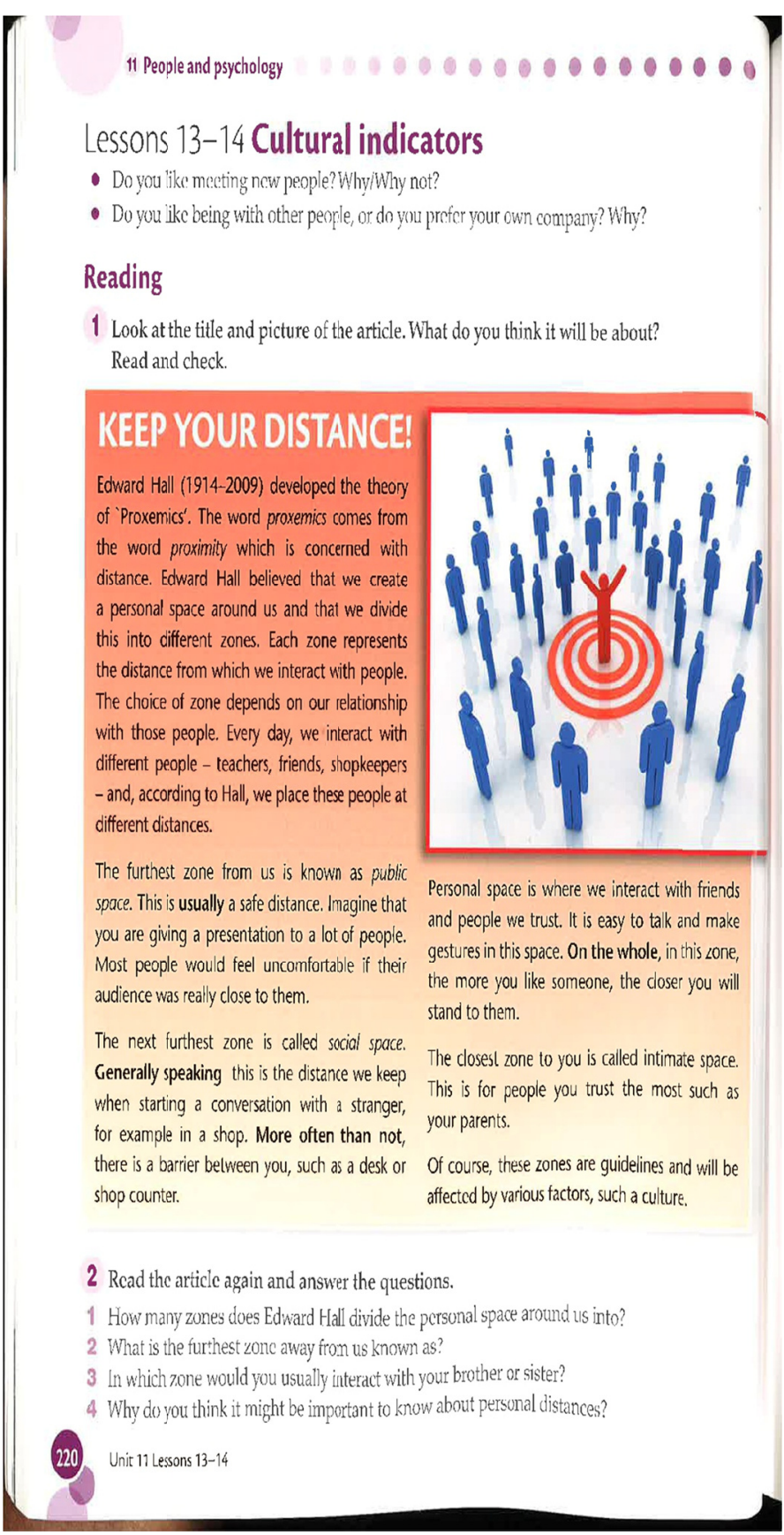

\section{Copyrights}

Copyright for this article is retained by the author, with first publication rights granted to the journal.

This is an open-access article distributed under the terms and conditions of the Creative Commons Attribution license (http://creativecommons.org/licenses/by/4.0/). 